\title{
Basites of the Vilyui - Markha zone (Siberian platform)
}

\section{M.D.Tomshin', A.S.Fomin² and B.V.Oleinikov'}

1-Institute of Geosciences, Siberian Branch, Russian Academy of Sciences, 677891 Yakutsk, Russia; 2 - "Almazy Rossii-Sakha” Co. Ltd., 678170 Mirny, Russia

The Middle Paleosoic $\left(\mathrm{D}_{2}-\mathrm{C}_{1}\right)$ was the period of high tectono-magmatic activity within the eastern Siberian platform. It was marked by the formation of the large Vilyuisk paleorift system (Levashov, 1975) accompanied by the emplacement of hypabyssal cross intrusions and sills, pipes, and lava and tuff magmatites of basic composition (Masaitis, 1966). On the northwest margin of the paleorift, the Vilyui - Markha dyke swarm was formed controlled by a zone of deep faults under the same name. The fault zone extends sublatitudinally for $700 \mathrm{~km}$ ranging in width from $30 \mathrm{~km}$ in the south to $70 \mathrm{~km}$ in the north (Fig.). The basic rocks occur here together with kimberlite diatremes making up the Malobotuobinsk and Nakynsk kimberlite fields in the southern and central parts of the fault zone, respectively.

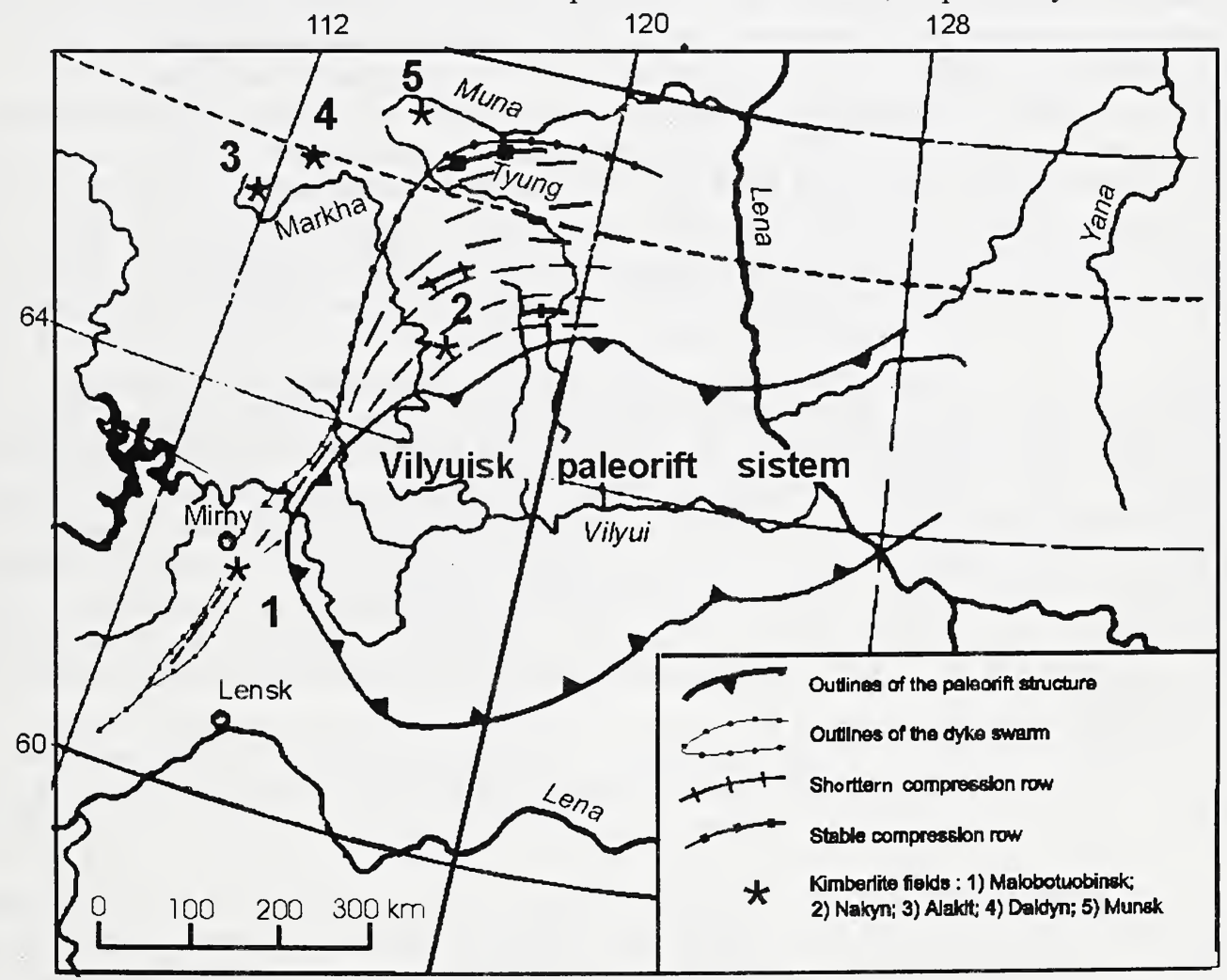

Fig. Location of the Vilyui-Markha dyke swarm.

Basic magmstism wifhin the central part of the dyke swarm is supposed to have been realized under dominant extension conditions. This is evidenced by a high concentration of dykes here, their linear character and great thickness (up to 120-150 m in places) as well as by the fact that some of the dykes widen to form chonoliths. The dykes and chonoliths are composed of ophitic and prismatic-ophitic gabbro-dolerites with phenocrysts comprising no more than $3 \%$ of the rocks in the marginal zones of the dykes. Plagioclase An $70-60$ is 
predominant though rare tabular crystals of zonal plagioclase with $\mathrm{An}_{83}$ in the core and $\mathrm{An}_{38}$ on the rims occur in all rock varieties. Monoclinic pyroxene corresponds to augite ( $\mathrm{WO}_{34}$ ${ }_{36} \mathrm{En}_{35-50} \mathrm{Fs}_{12-28}$ ). Hyalosiderite is replaced by bowlingite to a variable degree. In the center of the dykes hortonolite is present. The gabbro-dolerites include brown hornblende, biotite, guartz and lesser K-feldspar. Typical are high amounts of ore mineral oxides (up to 5\%) and apatite (up to $0-5 \%$ ). Magmatites from the periphery of the extension zone of the dyke swarm show evidence for magma retardation in the magma - feeding conduits on the way up to the surface. This led to the formation, in some cases, of dykes of taxitic - ophitic gabbro-dolerite with phenocrysts making up $10 \%$ of the rock and, in other cases, of leucocratic gabbrodolerite and plagiodolerite dykes containing up to $30 \%$ phenocrysts. High contents $(>5 \%)$ of phenocrysts of the minerals of the olivine, plagioclase and spinel series and of the early magmatic ilmenite, titanomagnetite and apatite provide direct petrological evidence for magma retardation in the magma channels and its crystallization there. Petrological geochemical composition of the bodies formed in such conditions is controlled, on the one hand, by crystallization properties of each of the above mentioned phases dependant on the viscosity of the evolving magma and, on the other hand, by the intensity of the process of emanation redistribution of elements in an extensive vertical magmatic column.

Dykes of taxitic - ophitic gabbro-dolerite are morphologically similar to those of prismatic - ophitic gabbro-dolerite. They are linear in nature and have a great length too, but they are not as much thick. This suggests that magma - controlling structures were formed under extension conditions which gave way to short-term compression. As a result, the ascent of the melt slowed down and it suffered a significant crystallization. The dykes contain phenocrysts of all the minerals of the above mentioned series. The groundmass of the taxitic - ophitic gabbro-dolerites is dominated by plagioclase $\mathrm{An}_{50-34}$ (60-66\%) occuring as large zonal prisms and tabular crystals with $\mathrm{An}_{88}$ in the center and $\mathrm{An}_{38}$ on the periphery. The palepink low - Ti augite has a composition of $\mathrm{W}_{37} \mathrm{En}_{42-46} \mathrm{Fs}_{17-21}$. Early olivine is represented by chrysolite, late olivine - by hyalosiderite, both are partly or completely replaced. High (up to $10 \%$ ) contents of ore mineral oxides are typical. Sphene is constant. In terms of petrochemical composition, the rocks show ranging amounts of $\mathrm{Si}$ and high alumina concentrations. $\mathrm{Mg}$ content reflects an insignificant loss of $\mathrm{Ol}_{1}$. A loss of $\mathrm{Ti}$ indicates the involvement of early magmatic ilmenite and augite in the process of magma differentiation. Analysis of parageneses of phenocrysts from these basic rocks suggests magma retardation at shallow depths where crystallization of $\mathrm{Pl}_{1}+\mathrm{Ol}_{1}+\mathrm{Py}_{1}$ occurred. In other words, the compression regime on the periphery of the extension zones was spatially restricted to the upper part of the magma-feeding conduits.

Another group of bodies uniting dykes of leucocratic gabbro-dolerite and plagiodolerite formed in the conditions of changing tectonic stresses, when extension gave way to stable compression. The dykes are less abundant here then in the extension zones. They are a few kilometers long, with rare intrusions measuring more. The dykes are found to tend to en-echelon arrangement. They are markedly thinner than the dykes in the extension zones (no more than $25-40 \mathrm{~m}$ ). Phenocrysts amount to $30 \%$ of the bulk of the rock. When describing such zones of compression it is advisable to use a term "ramp zone" where extension of the proper rift zone is compensated to produce thrusts and strike-slip faults which favour enechelon morphology of the fissure intrusions. Rocks of the dykes in the ramp zones are characterized by the presence of rare large (up to $3 \mathrm{~cm}$ ) and numerous small $(3-5 \mathrm{~mm}$ ) labradorite phenocrysts which provide for a porphyritic texture of the magmatites. The phenocrysts consist of $\mathrm{An}_{69-64}$ in the centre and $\mathrm{An}_{35}$ on the rims. Most of the prisms, small tabular crystals and laths have a more acidic composition: from $\mathrm{An}_{56-48}$ to oligoclase. Pelitized $\mathrm{K}$-feldspar is constantly present $(10-15 \%)$. It occurs either interstitially or overgrows or completely replaces plagioclase. Titaniferous augite $\left(\mathrm{WO}_{40} \mathrm{En}_{40-42} \mathrm{Fs}_{18-20}\right)$ is replaced by biotite to a variable degree and is often overgrown with hornblende. Olivine is absent in the 
leucocratic gabbro-dolerites. They contain high amounts of titanomagnetite which occurs as regular octahedral grains. The rocks are as high in $\mathrm{Al}, \mathrm{Na}, \mathrm{K}, \mathrm{Rb}, \mathrm{Ba}$ and $\mathrm{Pb}$ as those of the prismatic - ophitic dykes. The absence of olivine suggests a gravity settling of some of the phenocrysts together with early spinellide, which caused a decrease in the amount of $\mathrm{Mg}, \mathrm{Fe}$, $\mathrm{Ni}, \mathrm{Co}, \mathrm{Cr}, \mathrm{V}$ and $\mathrm{Sc}$ as compared to the basites of the extension zones. Estimation of a possible depth of action of compression regime in the magma channels of ramp zones, based on the phenocryst parageneses, suggests that it is comparable to the depth determined for the magma producing the taxitic - ophitic gabbro-dolerite dykes, i.e., the compression regime operated only in the upper part of the magmatic column. Noteworthy is a high fluid saturation of the heterogeneous parental substratum of the ramp zone dykes, mainly in $\mathrm{H}_{2} \mathrm{O}$ and $\mathrm{F}$, as compared to the dykes in the zones of short-term compression. It seems likely that volatiles and $\mathrm{K}$ were derived from an intermediate magma clamber located at the upper crustal level. Such chambers are quite possible in the zone of stable compensation compression.

Of interest are dykes of prismatic-ophitic gabbro-dolerite with anorthosite gabbrodolerite dykes within them showing an anorthositic differentiation trend (Oleinikov, Tomshin, 1976). They are spatially restricted to the periphery of the dyke swarm, at the boundary of the Vilyuisk paleorift system, and are in close proximity to the kimberlite pipes of the Nakynsk field. Their parental melt is supposed to have suffered a long fractionation in an intermediatelevel reservoir located at depth. Phenocrysts amount to as much as $60 \%$ of the rocks. Typical are fused cores of bytownite-anorthite composition and magnesian chrysolite. Cr- rich spinel, moissanite, apatite and native $\mathrm{Cu}, \mathrm{Zn}, \mathrm{Fe}, \mathrm{Pb}, \mathrm{Sb}$ and $\mathrm{Cd}$ occur as inclusions in $\mathrm{Pl}_{1}$ and $\mathrm{Ol}_{1}$. Heavy concentrates include high- $\mathrm{Cr}$ garnet and corundum. Alumina and $\mathrm{Ca}$ contents are high and $\mathrm{Mg}$ is low. Analysis of the early mineral parageneses suggests that retardation of magma which produced the dykes occurred at depths of $35-40 \mathrm{~km}$, at pressures ranging from 10 to 12 kbar.

Temporal relationships between kimberlite and basic magmatism of the Vilyui-Markha zone are ambiguous. The presence of dolerite xenoliths of Middle Paleosoic age and basalts of the Appaya formation $\left(\mathrm{D}_{2}\right)$ in the kimberlite pipes of the Malobotuobinsk field strongly indicates that basic magmatism predated kimberlite one. No xenoliths of basic composition were found in the kimberlites of the Nakynsk field. Geological studies carried out in the region revealed that prismatic - ophitic gabbro-dolerites of a presumed Devonian age and kimberlites of the Nyurbinskaya pipe are injected by alkali basites $\left(\mathrm{SiO}_{2}-44,7 \%, \mathrm{~K}_{2} \mathrm{O}-6,6 \%, \mathrm{Na}_{2} \mathrm{O}-\right.$ $0,5 \%$ ). The kimberlites and both basite varieties are, in their turn, altered by the rocks compositionally similar to carbonatites. From what has been said above it follows that an active magma system lived long at depth in the Nakynsk kimberlite field which provided for the following sequence of emplacement of magmatic rocks: tholeiitic basalts, including intrusions with an anorthositic differentiation trend - kimberlites - alkali basalts carbonatites.

\section{References}

Levashov,K.K., 1975. A Middle paleoroic rift system in the eastern Siberian platform. Sovetskaya geologiya, № 10, p. 49-58.

Masaitis, V.L., 1966. Devonian volcanism of the Siberian platform. Informatsyonnoye soobshcheniye. Vyp. 1, 14 pp.

Oleinikov, B.V. and Tomshin, M.D., 1976. Deep-level differentiation of parental magmas of platform basites. Dokl. AN SSSR, v. 231, № 1, p.177-180. 